\title{
Analisis perpindahan tenaga kerja informal Kabupaten Pasuruan
}

\author{
Kusuma Wijaya; Muhamad Imam Syairozi*
}

\author{
Prodi Manajemen, Fakultas Ekonomi Universitas Islam Lamongan \\ *E-mail korespodensi:imamsyairozi@unisla.ac.id
}

\begin{abstract}
Abstrck
The uneven economic growth causes regions to experience economic and social inequalities, which in the end they choose to look for a place that is expected to be able to meet their physical and spiritual needs. This study aims to determine the dominant factors that influence the decisions of informal workers to migrate to Pare District, Kediri Regency. The method of collecting direct data is by conducting interviews with respondents. The data obtained were then analyzed by the SPSS program using logistic regression analysis. The independent variables studied include: age (X1), an education level (X2), land ownership (X3), marital status (X4), employment status (X5), income (X6) and the dependent variable in this study is the decision to migrate. (Y). Based on the data collected from 102 respondents, it is known that the variables age (X1), land ownership (X3), and income (X6) have a significant effect on the reasons a person decides to migrate to Sukorejo District, Pasuruan Regency. While the education variable (X2), marital status (X4), and employment status (X5) were not significant. The income variable (X6) is the variable that most dominantly influences the decision of an informal worker to migrate to Sukorejo District, Pasuruan Regency
\end{abstract}

Keywords: Population growth, Informal workforce, Migration

\begin{abstract}
Abstrak
Pertumbuhan ekonomi yang tidak merata mengakibatkan wilayah mengalami kesenjangan ekonomi dan sosial, yang pada akhirnya mereka memilih untuk mencari tempat yang diharapkan bisa mencukupi kebutuhan jasmani dan rohaninya. Penelitian ini bertujuan untuk mengetahui faktor-faktor dominan yang mempengaruhi keputusan tenaga kerja informal untuk melakukan migrasi menuju Kecamatan Pare Kabupaten Kediri. Metode pengumpulan data langsung melakuakan wawancara dengan responden. Data yang diperoleh kemudian dianalisis dengan program SPSS menggunakan analisis regresi logistik. Variabel independin yang diteliti antara lain: usia (X1), tingkat pendidikan (X2), kepemilikan lahan (X3), status perkawinan (X4), status pekerjaan (X5), pendapatan (X6) dan variabel dependen dalam penelitian ini adalah keputusan melakukan migrasi (Y). Berdasarakan data yang di kumpulkandari 102 responden diketahui bahwa variabel usia (X1), kepemilikan lahan (X3) dan pendapatan (X6) berpengaruh secara signifikan terhadap alasan seseorang memutuskan untuk melakukan migrasi menuju Kecamatan Sukorejo Kabupaten Pasuruan. Sedangkan variabel pendidikan (X2), status perkawinan (X4) dan status pekerjaan (X5) tidak signifikan. Variabel pendapatan (X6) merupakan variabel yang paling dominan mempengaruhi keputusan seseorang tenaga kerja informal migrasi menuju Kecamatan Sukorejo Kabupaten Pasuruan
\end{abstract}

Kata kunci: Pertumbuhan penduduk, Tenaga kerja informal, Migrasi 


\section{PENDAHULUAN}

Populasi penduduk sendiri meningkat disebabkan pertumbuhan penduduk yang begitu cepat. Dinamika pertumbuhan penduduk merupakan proses menuju penyeimbangan jumlah penduduk yang meliputi: kelahiran, kematian dan mobilitas penduduk (Mantra, 2015). Indonesia merupakan salah satu negara berkembang yang memiliki jumlah penduduk begitu banyak mencapai 258.705.000 jiwa (BPS, 2016). Dengan jumlah penduduk yang begitu banyak mengindikasikan semakin banyaknya tenaga kerja yang tersedia serta menjadi salah satu penyebab mobilitas penduduk, karena perbedaan geografi sebuah wilayah dan perbedaan sumber daya alam. Memang dari berbagai penelitian fenomena migrasi banyak mewarnai negara berkembang, khususnya negara Indonesia yang memiliki jumlah penduduk yang begitu besar. Jumlah penduduk yang tinggal di daerah desa yaitu 119.321.070 jiwa, sedangkan penduduk yang tinggal di kota yaitu 118.320.256 jiwa (Sensus Penduduk 2010). Proses migrasi dalam suatu negara merupakan proses alamiah yang akan menyalurkan surplus tenaga kerja di daerah-daerah ke sektor industri modern di kotakota yang memiliki daya serap tenaga kerja yang lebih tinggi.

Migrasi merupakan salah satu langkah awal dari rumah tangga pedesaan untuk menyelamatkan mata pencaharian mereka dan untuk bearadaptasi dengan lingkungan ekonomi yang berubah sangat cepat (Syafitri, 2012). Perpindahan penduduk sendiri terbagi menjadi dua yaitu perpindahan tetap dan perpindahan sementara (Mantra, 2015). Berbagai alasan seseorang untuk mengambil keputusan melakukan migrasi ke daerah perkotaan. Menurut Bogue, 1959 (dalam Mulyadi S. 2014), diantara faktor-faktor yang mempengaruhi seseorang melakukan migrasi, yaitu kondisi ekonomi, peningkatan perkawinan, penawaran tenaga kerja, bencana alam, biaya pindah, informasi yang semakin berkurang di daerah asal. Dapat dipahami faktor penyebab terjadi migrasi sangat komplek. Faktor-faktor pendorong (Push Factors) yang terdapat di daerah asal ternyata tidak saja terdiri dari faktor ekonomi dan geografis, tetapi juga melibatkan faktor sosio-kultural dan demografis. Menurut Todaro, bahwa migrasi berkembang karena perbedaan antara pendapatan yang diharapkan, hal terjadi di pedesaan 3 dan perkotaan. Sukses atau gagalnya migran akan menimbulkan umpan balik yang positif atau negatif terhadap daerah asal mereka. Ketimpangan perekonomian antara daerah desa dan daerah kota menjadi lebih rasional ketika seseorang menginginkan perpindahan untuk menuju tempat yang memiliki pendapatan yang lebih tinggi daripada daerah asalnya untuk memenuhi kebutuhan sehari-hari. Gelombang pembangunan perekonomian sektor industri di daerah perkotaan yang begitu pesat dan menawarkan upah yang relatif tinggi merupaka salah satu faktor penarik (Pull Factors) para calon migran untuk melakukan mobilitas menuju daerah kota.

\section{KAJIAN PUSTAKA}

\section{Pengertian dan konsep migrasi}

Menurut Everett S. Lee (dalam Mantra, 2015), volume migrasi disuatu wilayah berkembang sesuai dengan tingkat keragaman daerah-daerah diwilayah tersebut. Di daerah asal dan didaerah tujuan. Menurut Lee, terdapat faktor-faktor yang terdiri dari: a).Faktor positif (+) yaitu faktor yang memberi nilai keuntungan apabila seseorang bertempat tinggal menempati tempat tersebut yang dijadikan tujuan. b).Faktor negatif (-) yaitu faktor yang memberikan nilai negatif atau merugikan jika seseorang tinggal di tempat tersebut, sehingga seseorang akan berpindah ke tempat lain, karena kebutuhan yang diharapkan tidak terpenuhi. C).Faktor Netral (0) yaitu 
faktor yang tidak mempengaruhi seseorang individu untuk tetap tinggal di tempat asal atau pindah ketempat lain.

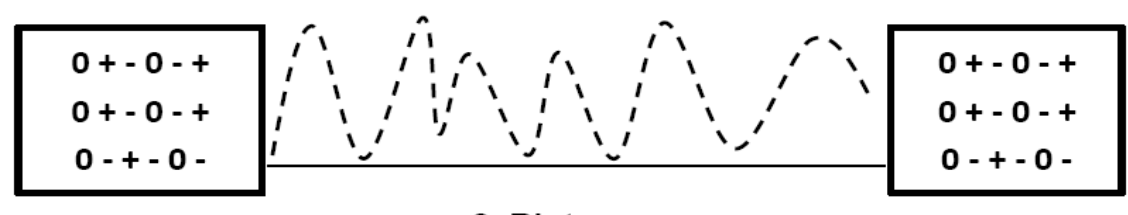

2. Rintangan
1. Daerah Asal
4. Individu
3. Daerah Tujuan

Sumber: Mantra, 2015

Gambar 1. Faktor-faktor determinasi penduduk ,enurut Everett S.Lee (1976)

Menurut Lee (1987) di kutip oleh Tim Peneliti PPIIS Universitas Brawijaya (1992) Beberapa Karakteristik Migran, yaitu: 1).Migran memiliki sifat selektif. 2).Migran pada umumnya memiliki ketertarikan pada daerah yang memberikan faktor-faktor positif pada diri mereka. 3).Migran tidak akan mengambil keputusan terhadap daerah yang tidak memberikan manfaat untuk keberlanjutan hidup mereka. 4)Secara keseluruhan, sifat selektif yang dilakukan migran cenderung bersifat dua bentuk. 5).Tingkat keputusan yang diambil oleh migran meningkat sebanding dengan rintangan antara yang menghambat. 6).Kecenderungan keputusan untuk bermigrasi tergantung pada perkembangan kehidupan (life Cycle). 7).Ada kecenderungan persamaan antara ciri-ciri penduduk daerah asal dengan ciri-ciri penduduk daerah tujuan.

\section{Kerangka pikir penelitian}

Adapun kerangka pemikiran dalam penelitian ini adalah:

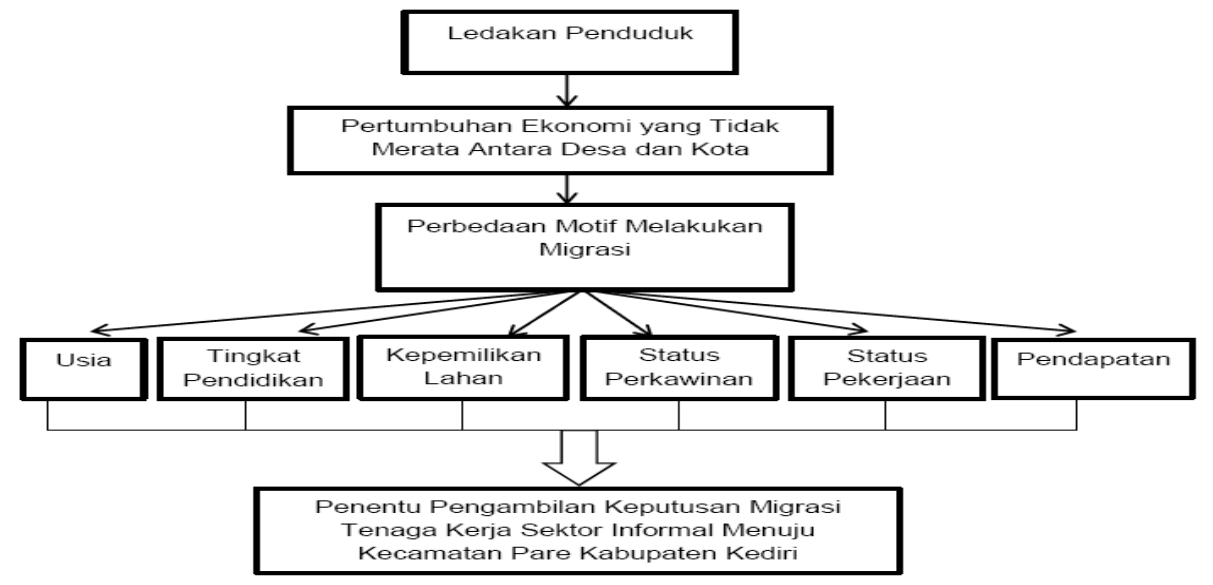

Gambar 2. Kerangka pemikiran

\section{METODE}

\section{Jenis dan pendekatan penelitian}

Jenis penelitian yang digunakan adalah deskriptif analitis (analytical descriptive approach) secara kuantitatif sesuai dengan rumusan masalah dan tujuan 
penelitian, dengan menggunakan metode survei. Tujuan dari penelitian ini untuk mendiskripsikan dan mengetahui fenomena-fenomena sosial maupun ekonomi yang mempengaruhi keputusan tenaga kerja informal bermigrasi menuju Kecamatan Sukorejo Kabupaten Pasuruan.

\section{Lokasi penelitian}

Penelitian ini dilaksanakan di Kecamatan Sukorejo Kabupaten Pasuruan. Merupakan Salah satu Kecamatan yang ada di kabupaten Kediri yang letaknya strategis dan Kecamatan ini mulai berkembang dengan ditandai perkembangan penduduk yang semakin banyak dan petumbuhan aktivitas bisnis yang semakin banyak, sehingga menarik para migran untuk mencari kerja di Kecamatan Sukorejo khususnya bekerja pada sektor informal.

\section{Populasi}

Populasi adalah sekumpulan generalisasi, baik itu terdiri dari subjek atau objek yang diteliti, yang memiliki karakteristik dan kualitas tertentu yang sudah ditetapkan oleh peneliti, kemudian dipelajari dan di ambil kesimpulannya (Sugiyono, 2004). Populasi dalam penelitian ini adalah pekerja sektor informal yang berada pada Kecamatan Sukorejo dan pekerja tersebut memiliki status migran.

\section{Sampel}

Sampel adalah kumpulan individu yang terpilih dari populasi yang memiliki karakteristik tertentu yang dianggap bisa mewakili populasi dari sebuah penelitian (Iqbal, 2002). Sampel yang diambil dari penelitian ini adalah penduduk pendatang yang berdomisili sementara di Kecamatan Sukorejo Kabupaten Kediri, dengan usia yang berbeda dan masih dalam usia produktif (15-64 tahun).

\section{Variabel penelitian}

Variabel adalah karakteristik atau keadaan yang dapat berubah atau memiliki nilai yang berbeda untuk individu yang berbeda (Frederick dan Larry, 2014). Variabel yang digunakan dalam penelitian ini adalah variabel ekonomi dan nonekonomi. Macam-macam variabel dalam penelitian menurut (Sugiyono, 2008), yaitu sebagai berikut:

\section{Variabel independen (bebas)}

Variabel independen adalah variabel yang mempengaruhi atau yang menjadi sebab perubahannya atau timbulnya variabel dependen (terikat). Karena sifatnya mempengaruhi variabel lain maka variabel independen dinyatakan dengan variabel (X). Variabel independen dalam penelitian ini antara lain: usia (X1), tingkat pendidikan (X2), kepemilikan lahan (X3), status perkawinan (X4), status pekerjaan (X5), pendapatan (X6).

\section{Variabel dependen (terikat)}

Variabel dependen adalah variabel terikat. Variabel terikat merupakan variabel yang dipengaruhi atau yang menjadi akibat, karena adanya variabel independen (variabel bebas). variabel dependen dalam penelitian ini adalah keputusan melakukan migrasi (Y). Model penelitian regresi logistik dalam penelitian ini dapat dituliskan sebagai berikut: 
$\mathrm{M}=\beta 0+\beta 1$ Usia $+\beta 2$ Tingkat Pendidikan $+\beta 3$ Status Perkawinan $+\beta 4$ Status Pekerjaan $+\beta 5$ Kepemilikan Lahan $++\beta 6$ Pendapatan $+\mathrm{e}$.

Keterangan:

M

Usia

Tingkat Pendidikan

Status Perkawinan

Status Pekerjaan

Kepemilikan Lahan

Pendapatan

B0

$\beta 1, \beta 2, \beta 3, \beta 4, \beta 5, \beta 6, \beta 7$
$=$ Keputusan bemigrasi.

$=$ Umur responden 25-54 tahun (usia prodiktif).

$=$ Pendidikan terakhir yang sudah ditempuh responden.

$=$ status sosial perkawinan.

$=$ pekerjaan informal responden.

$=$ kepemilikan lahan didaerah asal.

$=$ perolehan pendapatan responden.

$=$ Intersep

$=$ Koefisien regresi variabel independen.

$=$ Error Term

\section{HASIL DAN PEMBAHASAN}

\section{Analisis ekonometrika}

Analisis Ekonometrika merupakan alat hitung matematika yang digunakan untuk menjelaskan perilaku suatu variabel ekonomi. Dalam penelitian ini digunakan untuk menjawab rumusan, yaitu menganalisis migrasi tenaga kerja informal di Kecamatan Sukorejo Kabupaten Pasuruan maka penelitian ini menggunakan alat hitung logit (regresi logistik).

Tabel 1. Uji Hosmer and lemeshow test

\begin{tabular}{llll}
\hline Model & Chi Square & df & Sig. \\
\hline $\mathrm{Y}$ & 3,601 & 8 &, 891
\end{tabular}

Sumber: Data diolah, 2020

Pada model Y atau Migrasi Hosmer and Lemeshow Test pada tabe 4.91 dapat kita lihat hasil uji menunjukkan besarnya Chi Square hitung sebesar 3,601 dengan nilai signifikansi sebesar 0,891 dan sebagai pembanding didapat nilai Chi Square tabel dengan derajat kebebasan/degree of freedom (df) 8 sebesar 15,507. Karena nilai Chi Square hitung lebih kecil daripada Chi Square tabel yaitu 3,601<15,507 dan nilai signifikansi lebih besar dari alpha 5\% $(0,891>0,05)$. Sehingga dapat disimpulkan bahwa model yang digunakan memiliki probabilitas prediksi yang sama dengan probabilitas yang di amati sehingga dapat dikatan model ini layak untuk digunakan.

Tabel 2. Uji - 2 Log Likelihood

\begin{tabular}{llll}
\hline Interation & & $\mathbf{- 2} \log$ Likelihood & Coefficient \\
\hline \multirow{2}{*}{ Setp0 } & 1 & 141,363 & Constant \\
& 2 & 141,363 &,- 039 \\
& & &,- 039 \\
\hline
\end{tabular}

Ket: *Sebelum Variabel Independen (x) disertakan kedalam model Sumber: Data diolah, 2020

Berdasarkan Tabel 2 menunjukkan model Y atau migrasi nilai Model - 2 Log Likelihood tidak menyertakan variabel bebas sebesar 141,363 pada iterasi terakhir. Nilai tersebut dibandingkan dengan nilai - 2 Log Likelihood yang menyertakan 
variabel bebas sebesar 33,370 pada itersi terakhir lebih rendah. Kesimpulan dari model tersebut bahwa nilai- 2 Log Likelihood akan semakin kecil jika terjadi penambahan variabel bebas pada model, maka didapatkan model prediksi yang baik.

Tabel 3. Uji - $2 \log$ likelihood

\begin{tabular}{llcc}
\hline Model & $\mathbf{- 2} \log$ likehood & $\begin{array}{c}\text { Cox\&Snell R } \\
\text { Square }\end{array}$ & $\begin{array}{c}\text { NagelkerkeR } \\
\text { Square }\end{array}$ \\
\hline $\mathbf{Y}$ & $33,730^{\mathrm{a}}$ &, 652 &, 869 \\
\hline
\end{tabular}

Ket: Sesudah Variabel Independen (x) disertakan kedalam model

Sumber: Data diolah, 2020

\section{Uji Negelkerke's R Square}

Uji Negelkerke R Square, nilai R2 menunjukkan seberapa besar variabel variabel independen mampu menjelaskan variabel dependen. Berikut hasil uji Negelkerke R Square:

Tabel 4. Hasil uji Nagelkerke's R Square

\begin{tabular}{cccc}
\hline Model & $\mathbf{- 2} \log$ likehood & $\begin{array}{c}\text { Cox\&Snell } \mathbf{R} \\
\text { Square }\end{array}$ & $\begin{array}{c}\text { NagelkerkeR } \\
\text { Square }\end{array}$ \\
\hline $\mathbf{Y}$ & $33,730^{\mathrm{a}}$ &, 652 &, 869 \\
\hline
\end{tabular}

Sumber: Data diolah, 2020

Pada Tabel 4 tersebut dapat kita lihat, bahwa nilai Nagelkerke R2 $(0,869)$ hal ini menunjukkan bahwa variabel bebas yang termasuk dalam model dalam menjelaskan keragaman dari responden sebesar $86,9 \%$ dan sisanya sebesar $13,1 \%$ di jelaskan oleh variabel bebas diluar model.

\section{Uji regresi logistik secara parsial}

Uji secara parsial digunakan untuk mengetahui pengaruh variabel bebas terhadap variabel terikat, dengan melihat nilai signifikansi dalam tabel Parameter Estimates. Metode yang digunakan adalah metode ENTER dengan tingkat signifikansi sbesar 5\%, berikut tabel 5 yang menjelaskan tingkat signifikansi terhadap model Y yang di maksud adalah Migrasi.

Tabel 5. Uji regresi logistik secara parsial pada model

\begin{tabular}{lrr}
\hline Variabel & \multicolumn{3}{c}{ Model (Migrasi) } \\
\cline { 2 - 4 } & Sig & \multicolumn{2}{c}{ Exp (B) } \\
\hline usia &, 004 & 0,706 \\
Pendidikan &, 166 & 0,626 \\
Lahan &, 004 & 7,043 \\
Perkawinan &, 107 & 27.329 \\
Pekerjaan &, 999 & 119657,143 \\
Pendapatan &, 000 & 1,000 \\
Constanta &, 998 & .000 \\
\hline
\end{tabular}

Sumber: Data diolah, 2020

Berdasarakan Tabel 5 menunjukkan variabel yang lulus dari uji parsial dengan tingkat signifikansi $<0,05$ atau $5 \%$ adalah variabel usia $(0,004)$, variabel lahan $(0,48)$, dan variabel pendapatan $(0,000)$. 
Uji regresi logistik secara simultan (omnibus tests of model coefficients)

Berdasarakan Tabel 6 menunjukkan variabel yang lulus dari uji parsial dengan tingkat signifikansi $<0,05$ atau $5 \%$ adalah variabel usia $(0,004)$, variabel lahan $(0,48)$, dan variabel pendapatan $(0,000)$.

Tabel 6. Uji regresi logistik secara parsial pada model

\begin{tabular}{lcr}
\hline \multirow{2}{*}{ Variabel } & \multicolumn{2}{c}{ Model (Migrasi) } \\
\cline { 2 - 3 } & Sig & Exp (B) \\
\hline usia &, 004 & 0,706 \\
Pendidikan &, 166 & 0,626 \\
Lahan &, 004 & 7,043 \\
Perkawinan &, 107 & 27.329 \\
Pekerjaan &, 999 & 119657,143 \\
Pendapatan &, 000 & 1,000 \\
Constanta &, 998 & .000
\end{tabular}

Sumber: Data diolah, 2020

Uji regresi logistik secara simultan (omnibus tests of model coefficients)

Berdasarkan Tabel 7 dapat kita lihat bahwa nilai Chi Square hitung > dari Chi Square tabel pada DF 6 yaitu 107,663>12,592 dengan signifikansi sebesar $0,000<0,05 \%$ sehingga menolak $\mathrm{H} 0$, yang menunjukkan bahwa jika terjadi penambahan variabel independen maka dapat memberikan pengaruh nyata terhadap model atau dengan kata lain model dinyatakan fit dalam model.

Tabel 7. Uji regresi logistik secara simultan

\begin{tabular}{llll}
\hline & Chi-square & df & Sig. \\
\hline step & 107,633 & 6 &, 000 \\
Block & 107,633 & 6 &, 000 \\
Model & 107,633 & 6 &, 000
\end{tabular}

Sumber: Data diolah, 2020

\section{Hasil prediksi model}

Tabel 8 menjelaskan jumlah sampel yang melakukan migrasi dekat menuju Kecamatan Pare yaitu, sebanyak 49 orang. Jumlah sampel yang melakukan migrasi jauh menuju Kecamatan Pare yaitu, sebanyak 46 orang. Tabel di atas menjelaskan nilai overall percentage sebesar $(49+46) / 102=93,1 \%$, yang berarti ketepatan model dalam menjelaskan penelitian migrasi ini adalah sebesar $93,1 \%$.

Tabel 8. Klasifikasi

\begin{tabular}{lllccc}
\hline & Observed & & \multicolumn{3}{c}{ Predicted } \\
\cline { 3 - 4 } & & \multicolumn{3}{c}{ Migrasi } & $\begin{array}{c}\text { Percentage } \\
\text { Correct }\end{array}$ \\
\cline { 3 - 4 } Step 1 & Migrasi & $\begin{array}{l}\text { Migrasi } \\
\text { Dekat }\end{array}$ & $\begin{array}{c}\text { Migrasi } \\
\text { Jauh }\end{array}$ & \\
\hline & $\begin{array}{l}\text { Dekat } \\
\text { Migrasi } \\
\text { Jauh } \\
\text { Overall Percentage }\end{array}$ & 49 & 3 & 94.2 \\
& & 4 & 46 & 92,0 \\
\hline
\end{tabular}

Sumber: Data diolah, 2020 


\section{KESIMPULAN DAN SARAN}

\section{Kesimpulan}

Pekerja sektor informal di Kecamatan Pare cenderung memperoleh pendapatan hampir mendekati UMK Kabupaten Pasuruan . Hal ini menunjukkan bahwa kegiatan usaha sektor informal di Kecamatan Pare sedikit demi sedikit mampu mendorong pertumbuhan perekonomain di Kecamatan Sukorejo. Perekonomain yang baik dan terfokus akan menjadi prioritas calon migran menuju Kecamatan Sukorejo dari pada daerah lain, terutama migran dekat.

Pembahasan hasil uji regresi logistik dapat diketahui bahwa tiga dari enam faktor yang signifikan yaitu usia, kepemilikan lahan dan pendapatan migran. Pada sektor informal usia merupakan faktor yang sangat berpengaruh karena usia produktif migran pada saat itu (25-54 tahun), jadi masih giat-giatnya keinginan untuk melihat daerah lain yang menyediakan lapangan pekerjaan dengan pendapatan yang dianggap menjanjikan oleh migran. Status kepemilikan lahan juga berpengaruh pada sektor informal, Kepemilikan lahan dari migran pada daerah asal mempengaruhi pengambilan keputusan melakukan migrasi. Bagi migran yang tidak memiliki lahan mereka cenderung memilih menjadi migran yang pastinya dengan ketrampilan yang mereka dari daerah asal. Perolehan pendapatan juga sangat mempengaruhi seseorang melakukan migrasi, hal ini merupakan faktor ekonomi mengapa seorang memilih menjadi migran.

\section{Saran}

Melihat arus migrasi yang begitu deras menuju Kecamatan Pare Kabupaten Kediri, pemerintah harus terus melakukan perbaikan sarana dan prasarana yang ada di Kecamatan Sukorejo. Pada dasaranya seorang migran adalah tamu yang harus dilayani sebaik mungkin. Pada konteks ini jika para migran terkondisikan dengan baik maka sektor informal akan berkembang dan tidak akan mengalami kesenjangan sosial, sehingga hubungan migran dan penduduk asli akan tetap harmoni.

Selain itu pemerintah juga harus menyediakan pelatihan terhadap migran guna mendukung peningkatan produktifitas. Jadi para migran datang menuju Kecamatan Sukorejo tidak sekedar menjadi migran, namun juga mengembangkan kemampuan.

Penelitian yang peneliti lakukan masih banyak kekurangan, terutama pada varibel-variabel bebas yang digunakan sebatas usia, tingkat pendidikan, kepemilika lahan, status perkawinan, status pekerjaan, dan perolehan pendapatan migran. Variabel dummy yang digunakan dalam penelitian ini masih memiliki kelemahan, oleh karena itu tidak semuanya signifikan, hal tersebut disebabkan penggunakan variabel dummy yang kurang tepat. Diharapkan untuk peneliti selanjutnya dapat menambahkan variabel lain yang masih ada kaitannya dengan penelitian ini.

Pada penelitian ini data yang digunakan adalah data primer, sehingga ada keterbatasan waktu penelitian, sehingga sulit secara pasti mendapat data dari responden. Diharapakan untuk penelitian selanjutnya, untuk membuat schedule waktu penelitian supaya selesai tepat waktu.

\section{DAFTAR PUSTAKA}

Abidin, Zainal. (2013). Analisis Tenaga Kerja Melakukan Migrasi Komutasi Di Kecamatan Wuluhan Kabupaten Jember. Skipsi. Universitas Jember: Jember (tidak diterbitkan). 
Badan Pusat Statistik Republik Indonesia. (2019). Laporan Bulanan Data Sosial Ekonomi Agustus 2019. Diakses dalam https://www.bps.go.id/linkTabelStatis /view /id/1267 diakses 10 Juli 2020

Badan Pusat Statistik Jawa Timur. (2019). Berita Resmi Statistik Keadaan Ketenagakerjaan Jawa Timur, Agustus 2019. Diperoleh dari, jatim.bps.go.id/4dm!n/brs_ind/brsInd-20160504151856.pdf diakses 10 Juli 2020

Badan Pusat Statistik Kabupaten Pasuruan. (2019). Kabupaten Pasuruan dalam Angka 2019. Diperoleh dari, http://kedirikab.bps.go.id/index.php/Publikasi diakses 10 Juli 2020.

Badan Pusat Statistik Kecamatan Sukorejo. (2019). Kecamatan Sukorejo dalam Angka 2019. Diperoleh dari, http://kedirikab.bps.go.id/index.php/Publikasi diakses pada 10 Juli 2020

Badan Pusat Statistik Jawa Timur.(2019). Keadaan Angkatan Kerja di Jawa Timur. Diperoleh dari, http://jatim.bps.go.id/index.php/Publikasi diakses pada 10 Juli 2020

Gimba, Zaenab., dan Kumshe M.G. (2011). Causes and Effects of Rural-Urban Migration in Borno State: A Case Study of Maiduguri Metropolis. Asian Journal of Business dan Management Science, 1(1) 168-172.

Gravetter, Frederick j dan Wallnau, Larry B.(2014). Pengantar Statistika Sosial. Ed. 8. Salemba Empat: Jakarta

Hamidi. (2007). Metode Peneltian dan Teori Komunikasi. Malang: UMM Press.

Hartomo dan Aziz, Arnicun. (2011). MKDU Ilmu Sosial Dasar. Ed. 1. Jakarta: Bumi Aksara.

Hasan, M. Iqbal. (2002). Pokok-pokok Materi Metodologi Penelitian dan Aplikasi. Ghalia Indonesia.

Hashasa, Nisa dan Achma. (2012). Analisis Faktor- Faktor Yang Mempengaruhi Tenaga Kerja Menjadi Commuter dan Tidak Menjadi Commuter Ke Kota Semarang (Kasus Kabupaten Kendal). Diponegoro Journal Of Economics, Volume 1, Nomor 1, Tahun 2012, Halaman 1- 10.

Heer, David M.(1985). Masalah Kependudukan Di Negara Berkembang. Terjemahan Oleh G. Kartosapoetra. Bina Aksara Bandung

Munir, R. (2010). Migrasi dalam Lembaga Demograsi Fakultas Ekonomi Universitas Indonesia. Dasar - Dasar Demografi. Universitas Indonesia: Jakarta.

Prabowo, A.W. (2008). Analisis yang Mempengaruhi Ketepatan Waktu Pelaporan Keuangan Pada Perusahaan Manufaktur Yang terdaftar Di Bursa Efek Indonesia. Skripsi diterbitkan. Jakarta: Asia Banking-Finance and Informatics Institute Perbanas Jakarta. https://www.scribd.com/doc/45624921/36/Hosmerand-Lemeshow-Test-Goodness-of-fit-Test diakses 24 April 2015

Prayitno, Hadi. dan Santoso, Budi. (1996). Ekonomi Pembangunan. Yudhistira dan Balai Aksara: Jakarta:

Purwanto, Heru. (2012). Analisis Faktor-faktor yang Mempengaruhi Migran Sirkuler Tenaga Kerja dari Desa ke Kota, Studi Kasus: Kec. Tanjunganom Kab. Nganjuk Jawa timur 2012. Skripsi. Universitas Brawijaya: Malang (tidak diterbitkan).

Prawiro, Ruslan H. (1979). Kependudukan Teori, Fakta dan Masalah. Bandung Alumni: Jakarta 
Rahmadhania, Citra. (2013). Analisis Pendapatan Para Migran Sektor Informal Untuk Bertahan Hidup, Studi Kasus: Pedagang Berstatus Migran di Kota Malang. Skripsi. Universitas Brawijaya: Malang (tidak diterbitkan).

Ravenstein. (1985). Teori Migrasi. Pusat Penelitian Kependudukan UGM: Yogyakarta.

Syairozi, M. I. (2017) Percepatan Pengurangan Kemiskinan Sektor Pertanian di Kabupaten Malang. Seminar Nasional \& Call For Paper, FEB Unikama, 145155

Syairozi, M. I. (2017). Prospek Pengembangan Ilmu Ekonomi Islam Di Indonesia Dalam Prespektif Filsafat Ilmu (Sebuah Kajian Epistemik). JPIM (Jurnal Penelitian Ilmu Manajemen), 2(1), 311-326

Syairozi, M. I. (2017). Aplikasi Akad Musyarakah Pada Pembiayaan Unit Usaha Syariah Pt Bank Rakyat Indonesia (Persero), Tbk. Darul 'Ulum Islamic University, 1st International Conference on Islamic Civilization and Society 111-118 